\title{
ASSÉDIO MORAL NAS RELAÇÕES DE TRABALHO: OS REFLEXOS DO ASSÉDIO MORAL DIANTE DAS DIFICULDADES PROBATÓRIAS NAS DECISÕES JUDICIAIS E A RESPONSABILIDADE CIVIL E CRIMINAL DAS EMPRESAS
}

\author{
MORAL HARASSMENT IN WORK RELATIONS: THE REFLECTIONS OF MORAL \\ HARASSMENT BEFORE PROBATORY DIFFICULTIES IN JUDICIAL DECISIONS AND \\ THE CIVIL AND CRIMINAL RESPONSIBILITY OF COMPANIES
}

\author{
Eraldo Jesus Alves ${ }^{1}$ \\ Marcos Paulo Sales ${ }^{2}$
}

RESUMO: Este artigo tem como objetivo fazer um panorama do assédio moral nas relações de trabalho, destacando as diferentes visões e suas consequências. Pretende-se também chamar a atenção para a dificuldade de se provar o assédio moral em juízo, fazendo uma reflexão sobre a escassez de legislação específica e uma breve análise da importância da inversão do ônus da prova e a ampliação dos poderes do juiz em benefício do assediado. Além disso analisará a responsabilidade das empresas nos casos de ocorrência do assédio moral, apontando que seus códigos de conduta e códigos de ética não as isentam de penalidade. O que se tem de concreto sobre o tema é que a maior dificuldade no que concerne à penalização do assédio moral é justamente a sua "invisibilidade" e, portanto, o alto grau de subjetividade que está envolvido a questão.

Palavras-chave: Assédio Moral. Legislação Específica. Inversão do Ônus da Prova.

ABSTRACT: This article aims to provide an overview of bullying in labor relations, highlighting the different views and their consequences. It is also intended to draw attention to the difficulty of proving bullying in court, reflecting on the scarcity of specific legislation and a brief analysis of the importance of reversing the burden of proof and expanding the powers of the judge in favor of the harassed. In addition, it will analyze the liability of companies in cases of moral harassment, pointing out that their codes of conduct

\footnotetext{
IAluno especial do Programa de Pós-graduação Integração da América Latina (Prolam), da Universidade de São Paulo (USP). Bacharel em Direito pelo Centro Universitário Estácio da Bahia. Graduado em Comunicação Social com habilitação em Jornalismo pela Universidade Tiradentes (UNIT). Email: alves.eraldo@gmail.com.

${ }^{2}$ Doutorando do Programa de Pós-graduação em Mudança Social e Participação Política (ProMuSPP), na Universidade de São Paulo (USP), mestre em Planejamento Territorial e Desenvolvimento Social (MPTDS), pela Universidade Católica do Salvador (UCSal). Graduado em Comunicação Social com habilitação em Jornalismo. E-mail:mp.sales@usp.br.
} 
and codes of ethics do not exempt them from penalty. What is concrete about the theme is that the greatest difficulty in terms of penalizing moral harassment is precisely its "invisibility" and, therefore, the high degree of subjectivity involved in the issue.

Keywords: Moral Harassment; Specific Legislation; Reversal of the burden of proof.

\section{INTRODUÇÃO}

O tema proposto Assédio Moral nas Relações de Trabalho ao mesmo tempo que é considerado uma discussão recente, tendo o seu apogeu no final da década de 8o, é também um assunto que se faz presente no mundo do trabalho e na sociedade em geral desde o surgimento do trabalho.

Nas palavras da escritora francesa Marie-France Hirigoyen ${ }^{3}$, o assédio moral desestimula por completo o assediado tanto mentalmente como fisicamente. HIRIGOYEN (2002) observa o assédio nas relações trabalhistas como uma agressão que pode trazer dano à personalidade e à integridade física ou psíquica de uma pessoa

O estudo em questão, além de fazer um panorama do assédio nas relações de trabalho, destacando as diferentes visões do fenômeno, os tipos de assédio moral (vertical, horizontal e misto), os elementos caracterizadores e suas consequências, chama a atenção para a dificuldade de se provar o assédio moral em juízo, fazendo uma reflexão sobre a escassez de legislação específica e uma breve análise da importância da inversão do ônus da prova e a ampliação dos poderes do juiz em benefício do assediado. Abordaremos também sobre a responsabilidade das empresas nos casos de ocorrência do assédio, apontando que seus códigos de conduta e códigos de ética não isentam de penalidade.

A prática do assédio interfere no bom funcionamento das relações entre os indivíduos de uma sociedade, prejudicando o aprimoramento da vida de forma coletiva e individual.

\footnotetext{
3 Autora francesa estudiosa do tema assédio moral, Marie-France Hirigoyen tem como formação básica a Medicina, com Especialização em Psiquiatria, Psicanálise, Psicoterapia Familiar e Vitimologia. Sua última Especialização como vitimóloga, na área da Criminologia, realizada nos Estados Unidos da América, levou-a a analisar as múltiplas repercussões psíquicas em indivíduos que tinham sofrido agressões diversas. Autora das obras "Mal-Estar no Trabalho: Redefinindo o Assédio Moral" e "Assédio moral: a violência perversa no cotidiano, dentre outras sobre o tema assédio moral".
} 
Ou seja, não é uma prerrogativa da relação de emprego porque pode ser praticado em qualquer ambiente onde haja uma coletividade.

Um tema bastante discutido e de tamanha complexidade, o assédio moral é objeto de estudo de vários pesquisadores nas duas últimas décadas, chamando a atenção de sociólogos, trabalhadores, psicólogos, advogados, autoridades e demais pessoas interessadas pelo mundo do trabalho, que veem nessa questão uma forma de violação dos direitos dos trabalhadores.

Este trabalho tem como escopo contribuir no combate ao fenômeno assédio moral, mostrando suas consequências, de forma concisa, embasado em livros, entrevistas e artigos de estudiosos do assunto com intuito de transmitir e fazer com que a sociedade em geral tenha uma melhor compreensão, buscando o seu objetivo de visibilidade social para uma questão que é, altamente nociva e complexa, seja no ambiente de trabalho ou em qualquer lugar de convivência social.

Mesmo sabendo que a prática do assédio moral destrói a vida psíquica e a debilidade física do assediado, faz-se sensato buscar meios - seja através de leis e/ou políticas públicas de prevenção ao combate - para coibir essa prática nefasta, que em alguns casos termina com a morte de trabalhadores e trabalhadoras, alvo de uma perseguição abusiva e continuada.

A metodologia empregada neste artigo científico voltou-se em sua essência para os livros de estudiosos do tema, a exemplo da escritora francesa Marie France Hirigoyen, Margarida Barreto, precursora do assunto no Brasil, o juiz do Trabalho e professor Rodolfo Pamplona Junior, a juíza baiana Márcia Novaes Guedes e outros nomes de tamanha importância. Os relatos destes escritores foram essenciais para uma melhor compreensão do assédio moral e saber com maior profundidade o quanto nocivo seus efeitos na vida do assediado e aos que estão em sua volta.

No desenvolvimento e conclusão do tema, buscamos através de artigos, reportagens de sites, entrevista exclusiva com um juiz do trabalho do Tribunal Regional do Trabalho da Bahia - $5^{\underline{a}}$ Região Fiscal e recortes de matérias de jornal impresso que, além de colaborar na fundamentação do tema, serviu para um melhor entendimento sobre a "invisibilidade" e o alto grau de subjetividade que está envolvido o tema aqui estudado. 


\section{O ASSÉDIO MORAL NAS RELAÇÕES TRABALHISTAS}

Antes de falar sobre o assédio no ambiente laboral faz-se necessário destacar que esse terror psicológico no trabalho, vem desde a idade média da antiga Roma até os dias de hoje.

O homem, seja ele, escravo, prisioneiro de guerra ou trabalhador remunerado, sempre se deparou com o fantasma do assédio. Ou seja, como quase de forma unânime, diversos estudiosos do tema defendem que o assédio moral organizacional não é um fato novo. Poderia se dizer que ele é tão antigo quanto o trabalho. Deste modo, onde há trabalho pode haver o fantasma desta prática dando voltas a procura de sua vítima.

O escritor e mestre em Administração André Luiz Souza Aguiar, no livro "Assédio Moral nas Relações de Trabalho”, coletânea de palestras produzido pelo Unafisco Sindical Salvador, em agosto de 2009, afirma que:

“A discussão do termo assédio moral é recente. Mas, a discussão da violência no ambiente de trabalho, no Brasil, não, inclusive com pesquisadores de peso, sempre trazendo essa temática" (AGUIAR, 2009, p. 22).

Segundo AGUIAR (2009) há registros de violência no ambiente de trabalho no setor ferroviário (1868/1928), Setor de mineração (1932/1964), setor açucareiro (1972), setor industrial (1980) e setor bancário (1943/1985). Aguiar acrescenta que no Brasil, o ano de 1999 é o marco das discussões sobre o termo assédio moral.

AGUIAR (2009) explica que existe uma distinção entre alguns estudiosos do assunto sobre o que seja Assédio Moral e o Assédio Organizacional. Segundo ele, o assédio moral organizacional está dentro da matriz do assédio moral, mas oferece uma compreensão mais ampla do nosso cotidiano das organizações.

Isto não significa dizer que o assédio moral é uma questão e o assédio moral organizacional seja outra. No meu entender, estamos falando da mesma questão, pois este, quando influenciado pela psicologia, tende analisar o assédio moral apenas pelas relações interpessoais. (AGUIAR, 2009, p. 29) 
No Brasil, ainda existe uma confusão muito grande com relação ao tema. Conforme Aguiar, para ser considerado assédio moral, temos que ter uma repetição e uma sistematização do comportamento violento. $\mathrm{O}$ autor cita no livro, o assédio organizacional, conforme conceito elaborado pela procuradora do Trabalho de Brasília, Adriane Reis de Araújo, como:

Conjunto de condutas abusivas, de qualquer natureza, exercido de forma sistemática durante certo tempo, em decorrência de uma relação de trabalho, e que resulte no vexame, humilhação, constrangimento de uma ou mais vítimas com a finalidade de se obter o engajamento subjetivo de todo o grupo às políticas e metas da administração, por meio de ofensa aos seus direitos fundamentais, podendo resultar em danos morais, físicos e psíquicos. (AGUIAR, 2009, p. 29 apud ARAÚJO, 2006)

AGUIAR (2009) destaca o trabalho da médica do trabalho Margarida Barreto, precursora do assunto no Brasil sobre três pontos do assédio moral: no plano individual, organizacional e social.

No plano individual, nós temos a incapacidade do trabalhador, o seu adoecimento, o seu desemprego e aposentadoria. Nesta área de serviço, campo da minha atual pesquisa, a área de vendas, normalmente ocorre o desemprego. As pessoas conseguem se desvencilhar do emprego e ficam ali à deriva. Normalmente, os vendedores não se submetem, permanecem algum tempo no emprego, denunciam a violência e aos poucos, vão saindo do emprego. No plano organizacional, é caracterizado por muitas faltas do funcionário no trabalho, que seria absenteísmo, com alta taxa de rotatividade, custos elevados, inclusive na perda do valor do gasto em treinamento, e indenizações relativamente altas. No social, todos esses adoecimentos, toda essa aposentadoria precoce onera a Previdência Social, portanto, socialmente todos nós temos um ônus, um custo, além do suicídio e todo tipo de adoecimento. (AGUIAR, 2009, p. 35).

Os escritores Margarida Barreto, Maria Ester de Freitas e Roberto Heloani, observam o assédio moral como um problema organizacional que desencadeia no ambiente de trabalho com membros da própria estrutura laboral.

O assédio moral detém prerrogativas a partir de papeis organizacionais e encontra em questões ou aspirações organizacionais, o que torna a empresa corresponsável ou não isenta 
pelos atos culposos ou dolosos que ocorrem em seu interior. Explicitando aqui o conceito de que, para nós, o assédio moral é uma conduta abusiva, intencional, frequente e repetida, que ocorre no ambiente de trabalho e que visa diminuir, humilhar, vexar, constranger, desqualificar e demolir psiquicamente um indivíduo ou um grupo, degradando as suas condições de trabalho, atingindo a sua dignidade e colocando em risco a sua integridade profissional. (BARRETO, FREITAS, HELOANI, 2008, p. 37).

Aborda ainda estudos pioneiros sobre o tema, onde esclarece que diferentes autores, em diferentes países, utilizaram diferentes terminologias para falar sobre a violência psíquica. Ressalta sobre o trabalho desenvolvido pelo alemão Heinz Leymann, considerado o precursor dos estudos sobre o fenômeno que viria a ser conhecido entre nós como assédio moral. O escritor tinha como objetivo de seu trabalho sensibilizar assalariados, sindicalistas, administradores, médicos do trabalho e juristas para a gravidade da situação, incitando-os a combater e a prevenir esses processos destruidores.

Em 1993, Heinz Leymann lança o livro em que utiliza os termos em inglês mobbing e psicoterror no ambiente de trabalho.

Segundo o autor, o mobbing diz respeito a um processo no qual um indivíduo é selecionado como alvo e marcado para ser excluído, agredido e perseguido sem cessar por um indivíduo ou grupo no ambiente de trabalho. Essa perseguição pode vir de um colega, de um subordinado ou de um chefe. Ela é geralmente iniciada por algum desacordo não expresso com a vítima, que passa a ser objeto de preconceito, classificada como "uma pessoa difícil", incômoda e com quem é impossível conviver, portanto, sendo necessário livra-se dela. Uma vez desencadeado esse processo de terror psicológico, caso não haja intervenção externa, tende a ser reforçado pela omissão e pela conivência de superiores e colegas [...]. (BARRETO, FREITAS, HELOANI, 2008, p. 19 e 20 apud LEYMANN, 1993)

BARRETO, FREITAS, HELOANI (2008), deixam evidente no livro que a exposição dos trabalhadores a situações humilhantes e constrangedoras por longo período durante a jornada de trabalho são fatos cruciais para desencadear o assédio no ambiente laboral. 
Para HIRIGOYEN (2002), o assédio laboral é provocado por condutas abusivas que podem ser manifestadas em diversas formas, afetando bruscamente à personalidade do indivíduo, expondo o emprego em risco.

O assédio moral caracteriza-se antes de tudo pela repetição. São atitudes, palavras, comportamentos, que, tomados separadamente, podem parecer inofensivos, mas cuja repetição e sistematização os tornam destruidores (HIRIGOYEN, 2002, p. 30).

HIRIGOYEN (2002) traça uma distinção entre assédio moral e más condições de trabalho que se faz bastante pertinente.

As más condições de trabalho são de competência dos fiscais do trabalho, que devem ir ao local para verificar e punir. A dificuldade advém do fato de que, no caso do assédio moral, esta degradação é feita progressivamente, sem que a vítima possa julgar em que momento suas condições de trabalho se tornaram deterioradas. Se todo um grupo de empregados de uma mesma empresa vê suas condições de trabalho se degradarem, uma ação conjunta é possível. Por outro lado, uma pessoa sozinha inserida numa pequena estrutura poderá contar apenas com sua impressão subjetiva para ousar ou se queixar. No mais das vezes, o assédio moral é tão sutil, que a degradação das condições de trabalho de uma pessoa não aparece senão de modo relativo, pela comparação com a situação dos colegas. (HIRIGOYEN, 2002, p. 34).

Explica HIRIGOYEN (2002) em seu livro que, na origem dos procedimentos de assédio, não existem explicações óbvias, mas sim, um conjunto de sentimentos inconfessáveis, que se inicia repetidamente pela recusa de uma diferença e se manifesta por um comportamento no limite da descriminação. HIRIGOYEN (2002) reforça que, provavelmente, da discriminação chegou-se ao assédio moral, mais sutil e menos identificável para que não possa sofrer uma medida repressiva porque torna-se difícil aceitar um indivíduo que pensa de maneira crítica do seu grupo.

O que detestam naquele que pensa de outra maneira não é tanto a opinião diferente manifestada, mas a desenvoltura com que quer julgar por si próprio - o que, com certeza, eles nunca fazem e, no foro íntimo, têm consciência de não fazê-lo. (HIRIGOYEN, 2002, p. 38).

$\mathrm{Na}$ coletânea de palestras organizada pelo Unafisco Sindical Salvador, o desembargador Federal do Trabalho do TRT da $5^{\underline{a}}$ Região, Cláudio Mascarenhas Brandão, 
relatou que a discussão sobre o assédio moral e as suas consequências no contrato de trabalho é recente no Brasil, além de ser um tema novo entre os juízes do trabalho, principalmente após a Emenda Constitucional № 45, que ampliou a competência da Justiça do Trabalho para julgar as causas que envolvem acidentes do trabalho e doenças ocupacionais, que, em regra, causam lesão ao patrimônio imaterial.

Quando se fala em assédio moral, sempre se transmite a ideia de existência de lesão psíquica. Contudo, o tratamento que me parece mais adequado é compreendê-lo como violação da dignidade constitucional e abrange os atributos inerentes à personalidade humana: aquilo que possuímos pelo simples fato de sermos seres humanos, o que constitui diferença fundamental no tratamento dado ao tema. (BRANDÃO, 2009, p. 103).

BRANDÃO (2009), explica que o assédio moral causa lesão que ultrapassa a esfera do trabalhador, tendo que vista que estamos falando de ser humano que convive, mantém relações profissionais, afetivas e sociais e que, vítima de assédio, projeta essa consequência para muito além do ambiente profissional.

Para compreender essa abordagem, é imprescindível assinalar que apenas na Constituição de 1988 se introduziu no sistema jurídico brasileiro uma carta de princípios. Não havia precedente nas Constituições anteriores (BRANDÃO, 2009, p. 104).

Com palavras mais contundentes a juíza baiana Márcia Novaes Guedes discorre em sua publicação “Terror Psicológico no Trabalho" que o assédio moral, embora implique uma violação da intimidade do trabalhador, é algo muito mais grave.

Enquanto a violação da intimidade decorre do uso abusivo do poder diretivo do empregador, muitas vezes exagerando no uso de certas práticas voltadas para a proteção do patrimônio da empresa, o assédio moral, na realidade, decorre da atitude deliberada de um perverso cujo objetivo é destruir a vítima e afastá-la do mundo do trabalho. (GUEDES, 2003, p. 32).

Transportando para o mundo do trabalho, Assédio Moral ou Mobbing - termo empregado pela primeira vez por Konrad Lorenz -, famoso etimologista, segundo GUEDES (2003) significa: 
Todos aqueles atos e comportamentos provindos do patrão, gerente ou superior hierárquico ou dos colegas, que traduzem uma atitude de contínua e ostensiva perseguição que possa acarretar danos relevantes às condições físicas, psíquicas e morais da vítima. (GUEDES, 2003, p. 32).

Para DELGADO (2013) o assédio moral trata-se de figura de apreensão nova na doutrina e na jurisprudência trabalhistas, a partir de percepção de dinâmica ilícita experimentada na relação de emprego, porém sem necessário destaque antes da Constituição de 1998.

Define-se o assédio moral como a conduta reiterada seguida pelo sujeito ativo no sentido de desgastar o equilíbrio emocional do sujeito passivo, por meio de atos, palavras, gestos e silêncios significativos que visem ao enfraquecimento e diminuição da autoestima da vítima ou a outra forma de desequilíbrio e tensão emocionais graves. (2013, p. 650).

\section{AS DIFERENTES VISÕES DO FENÔMENO}

Mesmo que o fenômeno não seja recente, os estudos científicos que o abordam o são em termos relativos. É importante destacar que a noção de assédio moral difere de um certo número desses estudos e, em particular, do mobbing.

O termo mobbing, vem do verbo inglês to mob, cuja tradução é maltratar, atacar, perseguir, sitiar. Já o substantivo mob significa multidão, turba. Não se deve esquecer que, em inglês, Mob, com letra maiúscula, significa a máfia HIRIGOYEN (2002).

HIRIGOYEN (2002) relata em seu livro que na Inglaterra falou-se de mob após uma lista de nomes ter sido publicada em um jornal e grupos de mães enfurecidas assediaram pessoas suspeitas de ser pedófilos.

Nos anos 8o, Heinz Leymann, introduziu o conceito de mobbing, para descrever as formas ríspidas de assédio nas organizações. Antes, utilizado pelo etnólogo Konrad Lorenz.

Para Heinz Leymann, o mobbing consiste em manobras hostis frequentes e repetidas no local de trabalho, visando sistematicamente a mesma pessoa. Segundo ele, o mobbing provém de um conflito que 
degenera. É uma forma particularmente grave de estresse psicossocial. (HIRIGOYEN, 2002, p. 76 e 77).

Em 1993, Heinz Leymann publicou, a partir de suas pesquisas, uma obra de divulgação: Mobbing, lapersécution au travail (Mobbing, a perseguição no trabalho).

$\mathrm{Na}$ forma como é utilizado, o termo mobbing corresponde de início às perseguições coletivas e a violência ligada à organização, mas que podem incluir desvios que, progressivamente, transformam-se em violência física HIRIGOYEN (2002).

O conceito de bullying é conhecido há muito tempo na Inglaterra, em que bully significa agir com desumanidade. Falava-se do bullying essencialmente para descrever as humilhações e ameaças que crianças ou grupo de crianças atribuem a outras. $\mathrm{Na}$ Inglaterra e em alguns países de língua inglesa, continua sendo utilizado o termo bulliying. Em Quebec, onde se evitam palavras com conotação anglo-saxônica, fala-se de assédio psicológico.

A denominação bullying é aceita no Reino Unido e na Austrália (nos Estados Unidos se usa mais o termo mobbying), para se referir: a) ao comportamento ofensivo contra um indivíduo ou grupo de trabalhadores; b) a esses ataques que são imprevisíveis, desleais, irracionais e dificilmente notados pelos outros; c) ao abuso de poder que mina aos poucos a confiança e a autoestima da pessoa em foco; d) ao fenômeno visto como usado por quem tem poder ou posição para coagir por meio do medo, da perseguição, da força ou de ameaças. Portanto, essa denominação deixa implícito o fato de que o bullying ocorre basicamente entre uma condição superior a outra subordinada, limite que não é compartilhado por outros pesquisadores. (BARRETO, FREITAS, HELOANI, 2008, p. 23).

Nos Estados Unidos, o termo harassment somente foi introduzido em 1990 por um artigo de Heinz Leymann na revista americana Violence and victims, porém o fenômeno, já vinha sendo estudado desde 1976 pelo psiquiatra americano Carroll Brodsky, no livro intitulado The harassed worker. Da mesma forma que os outros termos já mencionados, o termo ijime (assédio em japonês) é utilizado não só para descrever as ofensas e humilhações infligidas às crianças no colégio, mas também para descrever, nas empresas nipônicas, as 
pressões de um grupo com o objetivo de formar os jovens recém-contratados ou reprimir os elementos perturbadores.

\section{TIPOS DE ASSÉDIO MORAL}

É preciso fazer uma distinção ente o assédio moral, que vem do empregador, e o que vem da hierarquia. Mesmo que estes sejam responsáveis pelo comportamento de seu pessoal, os empregadores, sobretudos nas grandes organizações, não são os únicos causadores do comportamento assediador no quadro de funcionários. Dentre os tipos de assédio moral, temos: Assédio vertical descendente, Assédio moral horizontal, Assédio moral vertical ascendente e Assédio Moral Misto.

HIRIGOYEN (2002) aponta que acontece o assédio moral vertical descendente quando os subordinados são agredidos pelos superiores hierárquicos.

Os motivos que levam a tal perseguição estão relacionados a forma autoritária com a falta de respeito e a exigência excessiva do chefe. Neste caso, o chefe geralmente usa seu poder dentro da empresa para humilhar e constranger determinado empregado, isolando-o dos seus colegas de trabalho, diminuindo suas atribuições, a fim de deixá-lo sem atividade. Muitas vezes, o empregado aceita toda situação em silêncio por temer a perda do emprego, rendendo-se, assim, aos ataques do agressor. (HIRIGOYEN, 2002, p. II2)

O assédio vertical descendente, conforme HIRIGOYEN (2002), é o mais comum tendo em vista que o assediado é a parte mais frágil na relação empregatícia e, na maioria das vezes, não tem conhecimento dos seus direitos.

É o tipo de assédio mais preocupante de todos, pois a vítima fica mais desamparada, tendo piores consequências psicológicas ou físicas HIRIGOYEN (2002).

No que tange o assédio vertical ascendente, DELGADO (2013) afirma que não é tão comum, porém, pode ocorrer de chefiados em direção a chefias.

O assédio moral perpetrado pelo empresário ou suas chefias constitui infração do empregador, que pode se capitular, por exemplo, nas alíneas "a", "b" ou "e" do art. 483 da CLT. Ou seja, conforme o artigo 483 da CLT. Sendo cometido por colegas de trabalho, pode ser capitulado nas alíneas " $b$ ", in fine, de " $j$ " da CLT, constituindo 
infração do(os) trabalhador(es) assediador(es). Mesmo neste segundo caso, entretanto, o empregador pode ser também responsabilizado pela vítima do assédio, em virtude de a ele competir a atribuição de criar e manter ambiente hígido de trabalho no estabelecimento e na empresa (art, 157, CLT). Ao atingir o próprio núcleo do patrimônio moral da pessoa humana que vive do trabalho, este tipo de assédio pode, sem dúvida, ensejar indenização por dano moral. (DELGADO, 2013, p.65o).

Já no assédio moral horizontal a vítima pode ser agredida de modo tanto individual como coletivo tendo em vista que é praticado pelos próprios colegas de trabalho cuja escala hierárquica é a mesma que a da vítima GUEDES (2003).

Este tipo de assédio é comum quando dois empregados concorrem à obtenção do mesmo cargo ou uma promoção. O mercado de trabalho está cada vez mais exigente e o relacionamento entre empregados passou a ser o mais competitivo possível GUEDES (2003).

GUEDES (2003) assevera que a ação discriminatória é desencadeada pelos próprios colegas de idêntico grau na escala hierárquica.

Os fatores responsáveis por esse tipo de perversão moral são a competição, a preferência pessoal do chefe porventura gozada pela vítima, a inveja, o racismo, a xenofobia e motivos políticos. Nessa espécie, a vítima pode ser golpeada de modo tanto individual como coletivo." (GUEDES, 2003, p. 37).

$\mathrm{O}$ assédio moral vertical ascendente ocorre com menos frequência, e está relacionado a casos em que um subordinado ou um grupo de subordinados assediam o seu chefe imediato ou dono da empresa.

A violência de baixo para cima geralmente ocorre quando um colega é promovido sem a consulta dos demais, ou quando a promoção implica um cargo de chefia cujas funções os subordinados supõem que o promovido não possui méritos para desempenhar. Claro que tudo isso e extremamente agravado quando a comunicação interna inexiste entre superiores e subordinados. (GUEDES, 2003, p. 37 e 38). 
Diante dessa situação, conforme GUEDES (2003), o chefe desrespeitado busca o isolamento no ambiente de trabalho por não conseguir se impor com o seu subordinado e com receio ser rebaixado de cargo.

Apesar de a estatística apontar os pequenos índices do mobbing ascendente em relação às outras espécies, a brutalidade e a violência praticada naquele não é menor do que nas demais modalidades GUEDES (2003).

$\mathrm{O}$ assédio moral misto envolve ao mesmo tempo o assédio moral vertical ascendente e o horizontal. Ou seja, o assediado é agredido tanto pelo superior hierárquico, quanto pelos colegas de trabalho.

Essa modalidade de assédio ocorre, geralmente, em empregos onde há alta competitividade interna, bem como em locais de trabalho onde o chefe ou patrão é bastante exigente GUEDES (2003).

\section{CARACTERÍSTICAS}

A intenção, o dano, a repetição, a premeditação, a existência de danos psíquicos ao agredido e a duração no tempo, são considerados pela maioria dos estudiosos como principais elementos configuradores do assédio moral nas relações de trabalho, HIRIGOYEN (2002) aponta que as manifestações podem ser as mais diversas, desde a deterioração proposital das condições de trabalho; do isolamento e recusa de comunicação; do atentado contra a dignidade até a violência verbal, física ou sexual.

$\mathrm{Na}$ deterioração proposital das condições de trabalho, segundo HIRIGOYEN (2002), é quando o assediador retira da vítima a sua autonomia e não lhe transmite as informações úteis para realização das tarefas, além de criticar as suas atividades e discriminá-lo, passa conscientemente metas impraticáveis de cumprir. $O$ assediador também não considera recomendações indicadas pelo médico do trabalho. 
No isolamento e recusa de comunicação, HIRIGOYEN (2002) explica que a vítima é isolada e os superiores hierárquicos e colegas não dialogam com ela. A comunicação é feita exclusivamente por escrito e recusa contato com a vítima.

Já no atentado contra a dignidade e violência verbal, o assediador faz gestos de desprezo diante do assediado e a desacredita diante dos colegas, crítica a sua vida privada e atribui tarefas humilhantes HIRIGOYEN (2002).

Quanto a violência verbal, física ou sexual, HIRIGOYEN (2002), o assediador chega a agredir a vítima fisicamente, mesmo que de leve. Invade a sua privacidade com ligações telefônicas, a assedia e/ou a agride sexualmente, além de não levar a sério a sua saúde.

\section{CONSEQUÊNCIAS}

A pessoa que é vítima do assédio no trabalho sofre consequências graves que abalam o organismo como um todo atingindo tanto a esfera psíquica quanto a esfera física, podendo, assim, ocasionar distúrbios que a afetaram a sua saúde para o resto de sua vida. GUEDES (2003) descreve que os danos na esfera emocional atingem por completo no cotidiano daquele que sofre o assédio, acarretando sérios problemas de relação familiar e social.

Sabemos que o trabalho é a principal fonte de reconhecimento social e realização pessoal. O homem se identifica pelo trabalho. Na medida em que a vítima sente que está perdendo sua capacidade de projetarse no futuro, verifica-se uma queda de autoestima e surge o sentimento de culpa; a vítima é tomada por grave crise existencial. A crise de relacionamento ocorre tanto na família quanto na esfera social. A relação familiar arruína-se na medida em que esta é a válvula de escape da vítima, que passa a descarregar sua frustação nos membros da família. (GUEDES, 2003, p. 94).

A pessoa que sofre o assédio se torna amarga, lamurienta e desagradável, abalando muitas vezes por completo o seu psicológico. Sendo que, os efeitos perversos do abuso moral não se limitam apenas ao trabalhador a ele submetido, mas espalham-se, em termos de custos, para as empresas que respondem pelas consequências diretas da violência no interior do grupo de trabalho. 
De modo geral, verifica-se, em nível de grupo, uma redução na capacidade produtiva e na eficácia; acentuada crítica aos empregadores; elevada taxa de absenteísmo por doenças; tendência do grupo de fazer tempestades em copo d'água, transformando pequenos problemas em gigantescos conflitos; a busca de bodes expiatórios, para mascarar os reais problemas e culpados. (GUEDES, 2003, p. 95).

Falar das consequências do assédio moral na saúde implica pensar nos danos psíquicos que podem apresentar-se como angústia e ansiedade, transtornando a existência.

$\mathrm{Na}$ fase de mal-estar, é comum o indivíduo sentir-se como se fosse um nada. As emoções são marcadas por pensamentos tristes, a vida perde o sentido e ele sofre de culpa e vergonha. Estão presentes a mágoa, a raiva e as incertezas, acompanhadas frequentemente de interrogações sem respostas ou de dúvidas constantes. O indivíduo tem uma avaliação negativa de si mesmo e pergunta-se constantemente "o que fiz", “onde errei [...]. (BARRETO, FREITAS, HELOANI, 2008, p. 77)

BARRETO, FREITAS E HELOANI (2008) discorrem sobre a prática do assédio e seus impactos e prejuízos arcados e imputados em diferentes graus sobrepostos e como manifesta em cada esfera: no nível individual, organizacional e social.

No individual, a vida psicossocial do sujeito, que, acometido por esse fenômeno tem atingidas a sua personalidade, identidade e a autoestima.

Diversos estudos demonstram que o assédio gera desordens na vida psíquica, social, profissional, familiar e afetiva do indivíduo, provocando muito problemas de saúde que podem desestabilizar a sua vida. Essas desordens reduzem a capacidade de concentração do indivíduo, induzem-no ao erro e colocam em risco tanto o seu emprego como a sua vida. Pesquisas europeias e brasileiras, trazem uma conta assustadora de problemas relacionados à depressão, aos pensamentos autodestrutivos $e$ às tentativas de suicídio entre as vítimas desse tipo de violência. $O$ afastamento do trabalho, a perda do emprego, o sentimento de nulidade e de injustiça, a descrença e a apatia podem ter efeitos colaterais assinados pelo alcoolismo e pelas drogas, gerando um círculo vicioso difícil de ser rompido. (BARRETO, FREITAS E HELOANI, 2008, p. 42).

Quanto ao nível organizacional, BARRETO, FREITAS E HELOANI (2008) apontam que são vários os efeitos nocivos, a exemplo, do afastamento de pessoal por doenças 
e acidentes de trabalho, a elevação de absenteísmo e a rotatividade com custos de reposição, a perda de equipamentos pela desconcentração, a queda de produtividade diante do moral do grupo e a qualidade do clima de trabalho, além dos custos judiciais quando das indenizações e tantos outros efeitos.

BARRETO, FREITAS E HELOANI (2008) ressaltam que o nível social praticamente tem sido ignorado, porém, defendem que todos numa sociedade têm um preço a pagar quando se massacram indivíduos pela prática de assédio.

Ora, diz respeito a todos nós: acidentes de trabalho e incapacitação precoce de profissionais, aumento de despesas médicas e de benefícios previdenciários (licenças, hospitalizações, remédios subsidiados, longos tratamentos médicos), suicídios, aposentadorias precoces, desestruturação familiar e social das vítimas, perda do investimento social feito em educação e formação profissional, custo potencial produtivo do profissional afastado por invalidez ou redução do seu potencial empregatício. Sempre que um profissional capaz torna-se incapaz, todos os indivíduos dessa sociedade pagam a conta. (BARRETO, FREITAS E HELOANI, 2008, p. 43)

\section{A INVERSÃO DO ÔNUS DA PROVA}

A inversão do ônus da prova cabe a quem: ao autor da ação ou ao réu. No que tange ao Assédio Moral, caberá o ter que provar ao assediado ou ao assediador? Conforme a escritora Maria Novaes Guedes, para vencer a questão, portanto, não basta ter razão, é preciso provar os fatos afirmados perante o juiz.

Ao decidir uma causa, o juiz faz um raciocínio lógico tomando por base os fatos narrados pelas partes e as provas documentais e orais.

No exame das causas, os juízes não podem decidir com base apenas nos seus sentimentos, no seu palpite pessoal, no "achologismo", por intuição. Não resta dúvida, porém, que, quanto maior a experiência do juiz de associar os saberes de várias áreas do conhecimento, inclusive o jurídico, a observação e experiência pessoal à solução prática dos problemas da vida, tanto maior as chances de acertar e fazer justiça. (GUEDES, 2003, p. 112).

Nosso Código de Processo Civil, art. 333, em dois incisos distribui assim o ônus da prova: Incumbe o ônus da prova: I - ao autor, quanto ao fato constitutivo de direito; II - ao 
réu, quanto a existência de fato impeditivo, modificativo ou extintivo do direito do autor. Já a Consolidação das Leis do Trabalho na sua simplificação técnica, resume tudo: "A prova das alegações incumbe à parte que as fizer" - art. 8ı, CLT.

Outro aspecto importante relacionado com a prova, conforme aduz GUEDES 2003, diz respeito à licitude dos meios de prova, pois a Constituição Federal, art.5ำ, LVI, declara que são inadmissíveis em juízo as provas obtidas por meios ilícitos.

Os tribunais vêm esclarecendo que somente no caso de a prova ser obtida com violação dos incisos X e XII do mesmo art. $5^{\circ}$ da CF, é que a prova será considerada imprestável. $O$ inciso $X$ trata da inviolabilidade da intimidade, da vida privada, da honra e da imagem pessoal e o inciso XII se refere à inviolabilidade da correspondência e das comunicações. (GUEDES, 2003, p. II2 e II3).

Sobre qual o tipo de prova que se pode adotar para fundamentar na alegação do de assédio, BRANDÃO (2009) responde:

Se se alega a ocorrência de ato único caracterizador de dano moral, a prova persegue um determinado objetivo; se ocorreu assédio, o caminho é diverso, mas difícil ainda, sem dúvida, pois além do fato em si, deve comprovar a repetição, a continuidade da conduta abusiva, o cerco, o que ne, sempre é fácil. A prova testemunhal é muito utilizada, mas representa uma dificuldade muito comum. (BRANDÃO, 2009, p. I09).

Quanto a licitude da prova, BRANDÃO (2009) assevera que:

Toda a prova é válida, desde que seja lícita, idônea, não é demais repetir. Discute-se muito hoje o conceito de licitude de prova, quando comparada (licitude) com o valor jurídico (dignidade da pessoa) posto em xeque. Em casos excepcionais, a doutrina aponta no sentido de privilegiar este último em detrimento daquele. (BRANDÃO, 2009, p. 109).

BARRETO, FREITAS, HELOANI (2008) defendem que o grande empecilho em se provar o assédio é justamente a sua "invisibilidade" e, portanto, o alto grau de subjetividade que está envolvido a questão.

O nexo causal, ou seja, a comprovação da relação entre consequência (no caso, o sofrimento da vítima) e sua causa (no caso, a agressão), indispensável na esfera criminal, nem sempre é a aparente. Isso porque tais humilhações são, geralmente, perpetradas "com luvas", 
ou seja, sem deixar as digitais do agressor. (BARRETO, FREITAS, HELOANI, 2008, p. 77).

NUNES (2013) defende que a distribuição do ônus da prova deve ser ordenada em consonância com as peculiaridades do caso concreto, respeitando os direitos fundamentais processuais, dos quais se destaca o princípio do devido processo legal.

“Em razão da hipossuficiência do empregado, os poderes instrutórios do juiz são mais resplandecentes no âmbito processual do trabalho, jamais devendo o magistrado se contentar em assistir passivamente a produção das provas carreadas ao processo por iniciativa das partes" (NUNES, 2013).

Afirma ainda NUNES (2013) que é grave a falta cometida pelo juiz que inclina seu poder para forçar a produção de provas que interessam e beneficiam apenas uma das partes.

Porém, tão ou mais grave é "a postura da indiferença à verdade, quando está ao alcance do juiz o meio de desvendá-la, e prefere julgar o litígio na sombra da indefinição e ao amparo da frieza técnica de pura distribuição legal do ônus da prova NUNES, 2013).

No âmbito processual do trabalho, LEITE (2014) frisa que atualmente parece não haver mais dúvidas sobre o cabimento do ônus da prova, não apenas pela aplicação analógica do art. 60, VIII, do CDC, mas também pela autorização contida no art. 852-D da CLT, in verbis:

O juiz dirigirá o processo com liberdade para determinar as provas a serem produzidas, considerado o ônus probatório de cada litigante, podendo limitar ou excluir as que considerar excessivas, impertinentes ou protelatórias, bem como para apreciá-las e dar especial valor às regras de experiência comum ou técnica. (CLT, Art. $852-\mathrm{D})$

LEITE (2014) adverte que pode ser analogicamente viável o art. 852-D da CLT a qualquer procedimento do processo trabalhista, com apenas uma advertência:

O princípio em tela só tem lugar quando não existirem outras provas nos autos suficientes à formação do convencimento do juiz acerca dos fatos alegados pelas partes (LEITE, 2014). 


\section{RESPONSABILIDADE CIVIL E PENAL DAS EMPRESAS}

Quando as empresas são alertadas sobre algum tipo de assédio moral, de imediato só pensam em negar. Objeto de inúmeras ações, das mais variadas formas possíveis, sendo todas com o intuito de reparação, decorrentes do dano sofrido.

De agora em diante, os dirigentes já não podem ignorar o problema. É sua vez de manifestar a vontade de colocar em prática um programa de prevenção em todos os escalões da empresa porque tão logo o assédio é detectado, seja ele horizontal (entre colegas) ou vertical (oriundo de hierarquia), é deles a responsabilidade, por ter deixado acontecer ou não terem sabido como evitar [...]. (HIRIGOYEN, 2002, p. 313).

BARRETO, FREITAS, HELOANI (2008) afirmam que geralmente o responsável pela indenização é o empregador e não a pessoa física que acarretou o dano ao trabalhador.

A indenização tem natureza punitiva e educativa e seu valor deve ter relação com a gravidade do dano e as condições financeiras do agressor e da vítima do dano BARRETO, FREITAS, HELOANI (2008).

Sobre os códigos de conduta e de ética, BARRETO, FREITAS, HELOANI (2008) são incisivos de que é preciso ser objetivo que os códigos de conduta e de ética não isentam a empresa de suas responsabilidades em casos da prática do assédio, principalmente quando as organizações foram negligentes.

Quanto a falta da responsabilidade civil das empresas torna-se necessário que se separe a responsabilidade civil do empregador em dois aspectos diferentes: quando o empregador comete o ato e quando trata da responsabilidade do empregador por ato de seu empregado. Sabemos de práticas que concretizam o assédio moral dificilmente poderão ser punidas devido o direito penal exigir maior rigor técnico na formulação de um tipo penal.

Para HIRIGOYEN (2002), de modo geral, uma lei é indispensável para mostrar que nossa sociedade se preocupa em não deixar que alguns cidadãos sejam maltratados e a fim de responsabilizar os empregadores. Ela relata que segundo Sandy Licari, "a criação de novas infrações penais não é panaceia, e a repressão não é sempre a melhor solução para erradicar 
comportamentos. [...] Contudo, a sanção penal demonstra definitivamente que são casos de comportamento maldosos intoleráveis aos olhos da sociedade".

Como a empresa deve se comportar diante de uma denúncia de Assédio? O advogado Rogério Lima, coordenador do Núcleo Trabalhista do Fiedra, Britto \& Ferreira Neto Advocacia Empresarial, em matéria publicada na Super Revista Abase, Órgão Oficial da Associação Baiana de Supermercados, em março de 2020, ressaltou que:

Inicialmente é salutar que se passe o ocorrido para o setor de Recursos Humanos da empresa e que também mantenha contato com o setor jurídico e, assim, possa sanar o problema evitando-se com outros personagens e também uma possível indenização. A empresa não vai querer ser responsável por um ato que foi praticado por um funcionário ou uma terceira pessoa. (ALVES, 2020, apud LIMA).

\section{DISTINÇÃO DO ASSÉDIO MORAL DO DANO MORAL}

Pode-se definir que o assédio moral ou dano psíquico está relacionado ao aparecimento de doenças psicopatológicas e o dano moral relacionado a lesão de direitos da personalidade. Conforme PAMPLONA (2014), o dano moral consiste no prejuízo ou lesão de direitos, cujo conteúdo não é pecuniário, nem comercialmente redutível em dinheiro.

Em outras palavras, podemos afirmar que o dano moral é aquele que lesiona a esfera personalíssima da pessoa (seus direitos da personalidade), violando, por exemplo, sua intimidade, vida privada, honra, imagem, bens jurídicos tutelados constitucionalmente (PAMPLONA, 2014).

Para BARRETO (2009), o assédio é uma manifestação da violência genérica. Deste modo, a violência vai além da mera agressão física, ela inclui o uso do poder e da força, que pode ser física, política, econômica, moral ou psicológica.

A violência é u $m$ fenômeno que o envolve o individual, ou seja, minha relação com o outro; a organização, ou melhor, a minha vida profissional dentro daquela organização; e a sociedade, explicitando a minha relação em família, com amigos e com outros. Compromete não só aquele que padece atos de violência, mas repercuti na família, danificando os laços de afetividade e demolindo todos os esforços e iniciativas daquele que sofre, inaugurando inquietações, frustações e sofrimento. É a dissolução dos laços afetivos nos intramuros e extramuros, que inaugura a insegurança. Repercussões que 
caracterizam um risco difuso e ampliando, na medida em que se origina no ambiente do trabalho e se ramifica para fora, manifestando-se em outros espaços sociais. (BARRETO, 2009, p. 40).

DELGADO (2013) afirma que o novo universo jurídico da Constituição de 1988 vislumbrou uma sequência irreprimível de situações fáticas em que se sustenta a ocorrência de violações a direitos da personalidade do trabalhador no contexto da relação empregatícia. Assinala ainda DELGADO (2013) que essas situações podem ser separadas em dois grupos relevantes: dano moral individual e dano moral coletivo.

No dano moral individual, DELGADO (2013) pontua que:

O dano moral possui, em regra, caráter individual, atingindo o patrimônio imaterial da pessoa humana. Atando-se ao complexo da personalidade do ser humano, espraia-se em múltiplas dimensões e facetas, capazes de produzir repercussões jurídicas diferenciadas no quadro das relações a que se integra a pessoa. (DELGADO, 2013, p. $645)$.

Já na definição do dano moral coletivo, DELGADO (2013), sustenta que o dano moral possui nítido caráter individual.

No contexto empregatício, entretanto, a conduta que a lesões de ordem moral ao ser humanos pode, sem dúvida, ter caráter massivo, largo, indiferenciado, de modo a atingir todo um núcleo coletivo circundante, seja o estabelecimento, seja a empresa, seja até mesmo uma comunidade mais abrangente - independentemente de seu necessário impacto também no plano individual dos trabalhadores. Trata-se de situações que extrapolam o campo meramente atomizado e individual da afronta e da perda, deflagrando, em face de sua sequência, repetição, multiplicação e expansionismo, um impacto comunitário próprio destacado. (DELGADO, 2013, p. 66o).

Ciente estamos que o prejuízo do assédio moral precisa ser provado e já com o dano moral não é necessário fazer prova de dor e sofrimento. Sobre esse contexto, BRANDÃO (2009) afirma que:

A caracterização do assédio moral pressupõe conduta abusiva reiterada, constante e repetida, isto é, não decorre, em regra, de ato único e, por isso, a sua ocorrência prática nem sempre é fácil de ser comprovada. Diante da dificuldade, o advogado opta em 
fundamentar o pleito na existência de simples dano, ao invés de fazêlo com base em assédio, pois, em caso deste último, terá que ser demonstrada a conduta abusiva e sua reiteração. $O$ universo probatório do qual irá se valer é trazido pela própria vítima, que nem sempre se mantém fiel aos acontecimentos. (BRANDÃO, 2009, p. I08).

O dano moral, por ser de responsabilidade civil, portanto, não é possível pleitear-se indenização sem a prova da existência de um prejuízo. Surte efeitos rigorosos no ser humano, em decorrência de ofensas à sua dignidade e à sua intimidade, causando-lhe profunda dor, tristeza e constrangimento. Ao contrário do dano material, o dano moral não afeta bens materiais, nem comercialmente redutíveis a dinheiro, mas lesiona a esfera personalíssima da pessoa e repercute no meio em que vive.

BARRETO, FREITAS, HELOANI (2008), defendem que embora o assédio moral e dano moral sejam fenômenos que caminhem juntos, tem conceitos distintos e ocasionam consequências jurídicas diferentes.

O assédio moral contém dano, ou melhor, é uma constelação de danos morais, de microtraumas psíquicos. Poderíamos ainda afirmar que, de fato, apesar de todo o assédio moral conter um conjunto de danos morais embutidos em si mesmo, nem todo dano moral constitui, por si só, um assédio moral. Dessa forma, embora sejam fenômenos que caminhem juntos de maneira compassada, são conceitos distintos e naturalmente acarretam consequências jurídicas diversas. Ampliando a interpretação, é possível afirmar que o assédio moral (e, por extensão, o sexual) é uma categoria ou espécie de dano moral que, devido a sua forma de expressão, temporalidade e frequência, apresenta singularidades. $\mathrm{O}$ dano moral é gênero. Esse dispositivo jurídico está previsto na Constituição Federal e no Código Civil do Brasil. (BARRETO, FREITAS, HELOANI, 2008, p. 90 e 9I).

\section{O ASSÉDIO MORAL E O ASSÉDIO SEXUAL}

O assédio sexual não se confunde com o assédio moral. Portanto, a sua distinção é fundamental. Sobre essa distinção Márcia Novaes Guedes relata que:

As pessoas, normalmente, tendem a confundir os termos "assédio moral" e "assédio sexual". Ambos são fenômenos que, em certos casos, guardam alguma relação, mas que se distinguem radicalmente 
porque, "enquanto o primeiro visa precisamente à eliminação da vítima do mundo do trabalho pelo psicoterror, o segundo visa a dominar a vítima sexualmente, normalmente pela chantagem. No assédio sexual, por razões culturais (machismo), a mulher ainda é vítima preferencial desse tipo de violência em todo o mundo" (GUEDES, 2003, p. 39).

Guedes (2003) salienta que assédio sexual não se confunde com o assédio moral. O assédio moral requer a presença de dois requisitos: duração no tempo e o objetivo de destruir a vítima; sendo que a natureza dos ataques (apelidos, calúnias, difamações) pode ter um fundo sexual, ou seja, sobre a preferência sexual da vítima. Já no assédio sexual, tem-se que a mulher ainda é a vítima preferencial, muito embora a jurisprudência comece a colher casos esporádicos de assédio sexual tendo o homem como vítima.

No Brasil, o assédio sexual não é uma prática recente. Na medida em que a mulher se insere no mercado de trabalho, aumenta também a sua exposição ao risco do assédio. Cada vez mais a mulher tem encontrado meios de merecer o respeito e a admiração das pessoas ao seu redor, seja com sua constante preocupação por aprender ou por ocupar cargos semelhantes aos dos homens.

Para PAMPLONA (2014), o assédio sexual é um dos temas laborais mais fascinantes da atualidade, que pode estar intimamente ligado com a relação de emprego.

Isso se deve segundo ele, em função da longa duração da jornada de trabalho ou do contato frequente imposto pelo desempenho das tarefas habituais, o certo é que o ambiente de trabalho facilita sobremaneira a aproximação dos indivíduos.

Caso esta circunstância se dê entre trabalhadores de nível hierárquico diferente e/ou entre empregador e empregado, em que uma das pessoas tem o poder de decidir sobre a permanência ou não da outra no emprego ou de influir nas promoções ou na carreira da mesma, caracterizado estará o assédio sexual, se a conduta do assediante ultrapassar os limites da razoabilidade, traduzindo-se em pressões de ameaças - explicitas ou implícitas - com o objetivo evidente de obter os favores sexuais do assediado. (PAMPLONA, 2014, p. 99).

Constata-se que o assédio moral traz em seu conteúdo a ideia de bloqueio, e em casos de assédio sexual não é diferente. Porém, ao adotar como base a categorização dos 
comportamentos hostis de assédio, descritos por HIRIGOYEN (2002), considera-se o assédio sexual como uma subcategoria de assédio moral, pois ao atentar contra a liberdade sexual do indivíduo, também atinge a dignidade psíquica do mesmo, o que configura assédio moral.

Segundo o advogado Rogério Lima, na Bahia, dados disponibilizados pelo Conselho Nacional de Justiça (CNJ) em 2017 e 2018, apontam que 7.728 pedidos envolvendo Assédio Moral deram entrada na $\underline{I}^{\underline{a}}$ instância da justiça do trabalho da Bahia em 2017, e na $2^{\underline{a}}$ instância, foram 2.21 pedidos no mesmo ano. Já em 2018, foram 3.330 pedidos na I $\underline{\text { a }}$ instância e I.988 na $2^{\underline{a}}$ instância. No que tange ao Assédio Sexual, foram 234 pedidos na ${ }^{\mathrm{I}}$ instância e 50 pedidos na $2^{\underline{a}}$ instância, em 2017. Já em 2018, o número reduziu para 8I pedidos na $\mathrm{I}^{\mathrm{a}}$ instância e 66 na $2^{\underline{a}}$ instância.

Conforme Lima, a diminuição no número de pedidos em 2018 se deve ao advento da Reforma Trabalhista, porém não diminuiu o assédio no ambiente de trabalho. "O receio de pagar os honorários advocatícios e sucumbenciais, teve um afunilamento dessas reclamações. Mas isso não quer dizer que tenha diminuído o assédio dentro das empresas”.

\section{A ESCASSEZ DE LEGISLAÇÃO ESPECÍFICA}

Temos consciência da ausência de leis que contribuam na penalização do assédio moral. No entanto, apesar dessa dificuldade de penalização, que se deve ao fator subjetivo que envolve esse tipo de delito, alguns países já têm um projeto de legislação específica para criminalizar o assédio no trabalho. É o caso de Portugal, Itália, Suíça e Bélgica (União Européia - Resolução nº 2.339/200I), da Noruega, do Chile e do Uruguai. Na maioria dos países, a situação é muito semelhante: a carência de um ordenamento específico que criminalize essa forma de tortura psicológica.

No Brasil, ainda não existe legislação específica que ampare o trabalhador da esfera privada e os servidores federais. Somente há legislações municipais e estaduais que tem por finalidade a prevenção dos ataques de assédio. 
Vereadores e deputados têm tentado criar uma legislação mais direcionada a esse fenômeno, no intuito de chamar para sua gravidade. Já existem várias leis municipais e algumas estaduais. No âmbito estadual, é o Rio de Janeiro que, desde agosto de 2002, desponta com uma legislação bastante completa. Ela combate o assédio moral de forma extensiva às empresas permissionárias ou concessionárias. (BARRETO, FREITAS E HELOANI, 2008, p. 83).

Toda legislação específica brasileira sobre assédio moral limita-se aos órgãos da administração pública municipal e estadual. O primeiro município brasileiro a reprimir o mobbing no âmbito municipal foi o de Iracemópolis, no estado de São Paulo. Em seguida, os municípios de Cascavel, no Paraná, com a Lei no 3.243, de 15 de maio de 2001. A cidade de São Paulo aprovou a Lei no 13.288 , de ro de janeiro de 2002.

Diante de um fenômeno tão antigo, como o assédio moral, e uma discussão aparentemente atual, vários países buscaram legislação específica para penalizar possíveis agressores, como tem-se visto na Itália, Alemanha, Suíça, Austrália e Estados Unidos. A ausência de lei específica, não tem impedido que o ofendido busque a tutela jurídica e os tribunais no Brasil têm manifestado sobre o assunto e o Poder Judiciário reconhece sua pertinência.

Em matéria publicada pela Folha UOL de 23 de março de 2009, intitulada "Casos de assédio moral crescem na crise”, Cláudio José Montesso, presidente da Anamatra (associação que reúne os juízes trabalhistas do país), relata da ausência de uma lei federal especifica no Brasil para regular o assédio. A publicação ressalta que no setor público, alguns Estados, como São Paulo e Rio de Janeiro, têm leis que tratam o assunto, protegem os funcionários públicos e preveem punição aos agressores. Para o setor privado, porém, não há regras.

Uma pesquisa feita pela Anamatra, relata que $79 \%$ dos juízes apontaram a necessidade de que o assédio moral seja regulamentado em lei.

A regulação é importante porque estabelece limites mais claros e critérios objetivos do que é ou não assédio, de que forma ocorre e como deve ser indenizado. Os juízes vão se sentir mais seguros na hora de julgar um caso. Hoje a interpretação é 
meramente subjetiva. (ROLLI e FERNANDES, 2009, apud MONTESSO).

Por outro lado, na nota, o advogado Luis Carlos Moro afirma ainda que alguns juízes e advogados trabalhistas discordam, entretanto, da necessidade de se criar uma lei.

A regulação seria nociva. Determinar regras restringe a liberdade do julgador ao considerar o que pode ou não ser assédio moral "(ROLLI e FERNANDES, 2009, apud MORO).

Em entrevista a UOL, o pesquisador Roberto Heloani, professor da FGV e da Unicamp relatou que: "Existe uma crise real e uma imaginária, que torna os funcionários mais inseguros e angustiados. Com essa tensão coletiva, o clima é de maior disputa. Quem está fora do mercado quer entrar, e quem está dentro não quer sair. Os gestores são mais pressionados, pressionam os empregados da produção, e as situações de assédio vão se alastrando", diz. "O número de consultas ao site (www.assediomoral.org.br) cresceu cerca de $20 \%$ desde que a crise se agravou, em outubro, afirma Heloani, que também é coordenador do site.

"Dez denúncias de assédio moral no trabalho são registradas por dia", matéria divulgada na edição do dia 28/05/2014 no Jornal Hoje (REDE GLOBO) e publicada no globo.com. O texto chama a atenção para o número de casos de assédio registrados no Brasil, por exemplo: "Mais de 3,6 mil casos de assédio moral foram registrados em todo Brasil no ano passado; "Qualquer tipo de humilhação dentro do ambiente de trabalho pode ser caracterizado como assédio moral e "Segundo o Ministério Público do Trabalho (MPT), os bancários são os que mais sofrem: de cada três ações por assédio moral, uma vem dessa categoria”.

O texto diz ainda que as denúncias por assédio moral cresceram $7 \%$ e as principais vítimas são mulheres, principalmente as grávidas e mães solteiras, pessoas mais velhas, obesas e negros. Conforme o MPT, os motivos que levam a essa relação de conflito são necessidade de aumentar a produtividade, competição exagerada, metas difíceis de alcançar 
e tentativa de forçar um pedido de demissão. Com um clima ruim, o rendimento do funcionário na empresa cai, ele passa a ter dificuldade de concentração e se sente inútil. $\mathrm{O}$ MPT adverte ainda que esses casos também costumam afetar a saúde. Há relatos de pessoas que começaram a sofrer de insônia, depressão, que perderam o apetite ou ganharam peso.

Uma outra matéria aborda o aumento do número de casos de assédio no Brasil. "Com crise, casos de assédio moral disparam e crescem 47\% no interior", publicada em 28/o5/2015 no site da globo.com. Um levantamento do Tribunal Regional do Trabalho mostra que o número de processos por assédio moral cresceu 47\% no Estado de São Paulo, em 2014, e que um dos motivos do aumento é a crise econômica, que pressiona o mercado de trabalho e afeta o relacionamento com os funcionários.

O gerente regional do trabalho em São Carlos, Antônio Valério Morillas Junior, esclarece que a busca da produtividade por parte das empresas e a sobrecarga de trabalho acabam adoecendo o empregado:

$\mathrm{Na}$ busca de maiores lucros, muitas vezes, por exemplo, se diminui o número de empregados de uma empresa e as tarefas daqueles que foram demitidos são distribuídas para os demais. E cada vez mais vai se jogando uma sobrecarga em cima do trabalhador através do assédio. Em um primeiro momento essa produtividade aumenta, mas depois, com a doença do trabalhador, começa a cair. (Portal Globo GI, 2015, apud MORILLAS).

A matéria também aborda sobre a ausência de lei especifica que prevê uma punição para o assédio moral.

A maior dificuldade para evitar esse comportamento no trabalho é a falta de uma lei específica que preveja punição, como é o caso do assédio sexual. Por isso, as provas são muito importantes e o Ministério do Trabalho lançou uma cartilha dando orientações sobre como proceder. (Portal Globo Gi, 2015, apud MORILLAS). 
Diz ainda na nota Morillas que, apesar de não haver lei específica, a Justiça tem reconhecido os casos de assédio.

A Justiça do Trabalho sempre esteve ao lado do trabalhador e tem sido muito enérgica, o que contribui para se diminuir esses casos (Portal Globo GI, 2015, apud MORILLAS).

Já o professor e juiz do Trabalho Rodolfo Pamplona Filho, em entrevista exclusiva para o fechamento deste artigo, realizada em Salvador, em 09/II/2015, relatou que a criação de uma lei especifica não vem solucionar o problema do assédio moral.

O assédio tipificado como crime não é a solução porque muitas vezes o campo de apuração é muito mais dificultoso. As pessoas acabam achando que transformar em crime todo ilícito era algo que combatia o ilícito, ledo engano, na verdade acaba tornando mais dificultosa a apuração por todo um arcabouço normativo que rege o sistema penal e o processo pena. (ALVES, 2015, apud PAMPLONA).

Pamplona esclarece ainda que o assédio atinge a todos e observa ambiguidades quanto a uma resposta criminal.

O assédio é um problema geral, não é apenas um problema que atinge homens e mulheres, é algo que está muito mais amplo dentro de uma mudança cultural. Tenho sérias dúvidas se a resposta criminal, como muitas vezes se propugna seja melhor. (ALVES, 2015, apud PAMPLONA).

"Vítima de assédio moral não tem a oportunidade de gozar seus direitos sociais no ambiente de trabalho", é título de matéria publicada pela Agência Brasil, de ıo/o9/2015. Na matéria, o Procurador do trabalho no Rio de Janeiro, Wilson Prudente, destacou aspectos prejudiciais do assédio moral para um funcionário no ambiente de trabalho.

A vítima de assédio moral não tem a oportunidade de gozar seus direitos sociais no ambiente de trabalho. E o Ministério Público do Trabalho é um órgão constitucional vocacionado para tutelar esses direitos. Temos de combater o assédio nas instituições. 
Para isso, devemos ter atitudes coletivas e individuais, porque a batalha é grande.; (Agência Brasil, 2015, apud PRUDENTE).

$\mathrm{Na}$ nota, o procurador alerta que há dois tipos de assédio moral: o individual e o institucional:

$\mathrm{O}$ individual, que parte de determinada pessoa ou de gestor, e o institucional, quando a empresa ou instituição está comprometida com uma modalidade de perseguição, seja ela racial, cultural ou religiosa, para, em alguns casos, assegurar determinados procedimentos corruptos. (Agência Brasil, 2015, apud PRUDENTE).

O advogado trabalhista Rogério Lima, explica que em se tratando do assédio moral ainda é muito difícil conceituá-lo e a legislação sequer trata do assunto.

Não existe lei específica informando o que é assédio moral, diferentemente do que ocorre com o assédio sexual, que existe uma lei penal que tipifica o assunto. Porém, o assédio moral é uma criação da Doutrina e Jurisprudência por conta das ações que ocorrem, principalmente nas relações de trabalho. (ALVES, 2020, apud LIMA).

No caso em que o assediado não tenha como provar que está sendo assediado, Lima alerta que procure um superior ou outro profissional dentro da empresa no mesmo patamar e relate o fato.

O correto é que essa agressão não se estenda. Porque, de fato, qualquer indenização que a pessoas vem a receber adiante não vai apagar o trauma, a dor de sofrer um assédio (ALVES, 2020, apud LIMA).

No Dário Oficial da União, precisamente, no dia 9 de novembro de 2015, foi criada a Lei no 13.185 que estabelece o Programa de Combate à Intimidação Sistemática (Bullying) em todo o Brasil. O texto sancionado pela presidenta Dilma Rousseff, caracteriza claramente as situações de agressão física, psicológica e moral que podem ser consideradas bullying e estabelece regras para definir casos de intimidação realizados por meio da internet. 
Em matéria publicada pelo Portal Brasil, em 09/II/2015, relata que o programa tem por principal objetivo prevenir e combater a prática da intimidação sistemática em toda a sociedade. O texto deixa claro que deve evitar, tanto quanto possível, a punição dos agressores, privilegiando mecanismos e instrumentos alternativos que promovam a efetiva responsabilização e a mudança de comportamento hostil.

\section{CONCLUSÃO}

O tema proposto tem como escopo fazer um mapeamento do assédio moral nas relações trabalhistas e mostrar que para a sua configuração é necessário apresentar uma totalidade de elementos caracterizadores, sendo preciso fazer uma distinção entre o assédio, que vem do empregador e o que vem da hierarquia.

Alerta ainda que essa prática causa lesão que ultrapassa a esfera do trabalhador, tendo em vista que estamos falando de ser humano que convive, mantém relações profissionais, afetivas e sociais e que, vítima de assédio, projeta essa consequência para muito além do ambiente profissional. No que tange as instâncias para denunciar o dano provocado pelo assédio, deve-se buscar a via judicial, onde será levada em conta a dificuldade na comprovação dos acontecimentos e dos danos.

Observa-se que a escassez de legislação específica ainda é o maior entrave para se provar o assédio moral. Ou seja, no Brasil, ainda não existe legislação específica que ampare o trabalhador de forma geral. O que há são legislações municipais e estaduais que tem por finalidade a prevenção do assédio.

Por outro lado, alguns juristas da área trabalhista e estudiosos do assunto acreditam que criar uma lei especifica para tipificar o assédio pode não ser uma solução porque muitas vezes o campo de apuração pode tornar-se mais dificultoso devido todo um arcabouço normativo que regem o sistema penal e o processo penal. Esse sistema mais protetivo de vulneráveis é próprio da área civil como um todo, incluindo o direito do Trabalho e o direito Administrativo. 
No que tange a inversão do ônus da prova percebe-se a complexidade quanto a quem deverá apresentar as provas, mesmo que o Código de Processo Civil em seu artigo 333 e a CLT com o 818 já tratem da questão. Portanto, para vencer a questão, não basta ter razão, é preciso provar os fatos afirmados perante o juiz. Porém, a distribuição legal do ônus da prova nem sempre atende às necessidades do processo trabalhista, podendo sobrecarregar o empregado, que não tem as mesmas condições e facilidades do empregador.

Assim, é possível sim a inversão do ônus da prova nos casos de assédio, mas ainda existe uma cultura se desenvolvendo nesta discussão. Mas também é preciso verificar pressupostos específicos para inversão do ônus da prova. Porém, não se deve inverter ônus da prova simplesmente porque o possível assediado é empregado ou coitadinho. Isso na verdade é transformar o poder judiciário em um mero instrumento de distribuição de renda ou de justiça social, e talvez não seja esse seu papel.

O que se percebeu durante a pesquisa deste artigo é que aos poucos vem se construindo políticas públicas de combate ao assédio moral dentro das empresas ou fora delas, seja no âmbito nacional ou internacional. E o Brasil já começou a intensificar essa luta com a criação da nova Lei no 13.185 de combate ao bullying, mas sabe-se o quanto é complexo o assédio nas relações trabalhistas e para prová-lo é preciso que o fato seja configurado como assédio e, antes de tudo, que o assediado tenha em mãos provas concretas que em juízo possa ser demonstrada e comprovada.

Por fim, a proposta deste artigo não pretende esgotar com o tema do Assédio Moral, que apesar de ser um tema novo é de existência tão antiga quanto o próprio trabalho. E, sim, analisar as maneiras pelas quais o assédio nas relações trabalhistas se manifesta, evidenciando-o como ato ilícito, violador de contratos e da dignidade da pessoa humana do trabalhador, dotando-o de visibilidade social.

\section{REFERÊNCIAS BIBLIOGRÁFICAS}

ALVARENGA, Flávia. "Dez denúncias de assédio moral no trabalho são registradas por dia" - Portal Gi Globo.com - Brasília - 28/o5/2014 - Jornal Hoje. Disponível em: 
http://gi.globo.com/jornal-hoje/noticia/2014/o5/dez-denuncias-de-assedio-moral-notrabalho-sao-registradas-por-dia.html. Acesso em: 4 out. 2020.

ALVES, Eraldo. "Como identificar, no trabalho, casos de assédio" - Super Revista Abase Órgão Oficial da Associação Baiana de Supermercados - Salvador - Bahia - Ano 26 № 296 - p. 24, 25 e 26 - março 2020. Disponível em: https://superrevista.com.br/wpcontent/uploads/2020/03/sr-marco-2020.pdf Acesso em: 4 out. 2020

BARRETO, Margarida. FREITAS, Maria Ester. HELOANI, Roberto. Assédio Moral no Trabalho - Coleção Debates em Administração - São Paulo - I⿳a ed. 2008.

CASCAVEL (Município). LEI № 3243/200. Dispõe sobre a aplicação de penalidades à prática de assédio moral nas dependências da administração pública municipal direta, indireta, autárquica e fundacional, por servidores ou funcionários públicos municipais efetivos ou nomeados para cargos de confiança. Leis Municipais Paraná - Cascavel. Disponível em: https://leismunicipais.com.br/a/pr/c/cascavel/leiordinaria/200I/324/3243/lei-ordinaria-n-3243-200I-dispoe-sobre-a-aplicacao-de-penalidadesa-pratica-de-assedio-moral-nas-dependencias-da-administracao-publica-municipal-diretaindireta-autarquica-e-fundacional-por-servidores-ou-funcionarios-publicos-municipaisefetivos-ou-nomeados-para-cargos-de-confianca Acesso em: 26 out. 2020

CAVALIERI Filho, Sérgio. Programa de Responsabilidade Civil. II $\underline{\underline{a}}$ ed. Revista e Ampliada. São Paulo - Atlas 2or4.

"Com crise, casos de assédio moral disparam e crescem $47 \%$ no interior" - Portal GI Globo.com - São Carlos e Araraquara - 28/05/2015 - Disponível em: http://gi.globo.com/sp/sao-carlos-regiao/noticia/2015/o5/com-crise-casos-de-assediomoral-disparam-e-crescem-47-no-interior.html. Acesso em: 4 out. 2020

DELGADO, Mauricio Godinho. Curso de Direito do Trabalho. $12^{\underline{a}}$ ed. - São Paulo - Editora $\mathrm{LTr}-2013$.

GUEDES, Marcia Novaes. Terror Psicológico no Trabalho. 2. ed. São Paulo: Ltr., 2003.

HIRIGOYEN, Marie-France. Mal-Estar no Trabalho: Redefinindo o Assédio Moral. Tradução de Rejane Janowitzer. Rio de Janeiro: Bertrand Brasil, 2002.

IRACEMOPILIS (Município). LEI N ${ }^{\circ}$ I.I63, DE 24 DE ABRIL DE 200o. Dispõe sobre a aplicação de penalidades à prática de assédio moral nas dependências da Administração Pública Municipal Direta por servidores públicos municipais. Iracemápolis-SP - Legislação Digital. Disponível em: https://www.legislacaodigital.com.br/IracemapolisSP/LeisOrdinarias/II63 Acesso em: 26 out. 2020.

LEITE, Carlos Henrique Bezerra. Curso de direito processual do trabalho. 12 ed. - São Paulo: LTr, 2014. 
NUNES, Gustavo Henrique Schneider. A dificuldade probatória do assédio moral no trabalho. Revista Jus Navigandi, ISSN 1518-4862, Teresina, ano 18, n. 3679, 28 jul. 2013. Disponível em: https://jus.com.br/artigos/24318. Acesso em: 3 out. 2020.

PAMPLONA Filho, Rodolfo. WYZYKOWSKI, Adriana. BARROS, Renato Costa Lino de Goes. Assédio Moral Laboral e Direitos Fundamentais. São Paulo: LTr, 2014.

Programa de Combate à Intimidação Sistemática (Bullying) em todo o Brasil - Portal Brasil, Brasília, o9 nov. 2015. Disponível em: https://www.in.gov.br/web/guest/materia//asset_publisher/KujrwoTZC2Mb/content/id/30174706/dor-2015-II-o9-lei-n-13-185-de-6de-novembro-de-2015-30174702 Acesso em: 3 out. 2015

ROLLI, Cláudia, FERNANDES, Fátima - "Casos de assédio moral crescem na crise" Folha de São Paulo UOL - São Paulo - 23/03/2009 - Seção: Mercado. Disponível em: https://wwwi.folha.uol.com.br/mercado/2009/03/538937-casos-de-assedio-moral-crescemna-crise.shtml. Acesso em: 3 out. 2015

SÃO PAULO (Lei Municipal). LEI № 13.288, Io DE JANEIRO DE 2002. Dispõe sobre a aplicação de penalidades à prática de "assédio moral" nas dependências da administração pública municipal direta $e$ indireta por servidores públicos municipais. Leis Municipais São Paulo - SÃO PAULO. Disponível em:

Seminário Assédio Moral nas Relações de Trabalho. Livro organizado pela Unafisco Sindical Delegacia Sindical Salvador, Agosto de 2009 - Gráfica Santa Bárbara - Salvador Bahia. https://leismunicipais.com.br/a/sp/s/sao-paulo/lei-ordinaria/2002/1329/13288/leiordinaria-n-13288-2002-dispoe-sobre-a-aplicacao-de-penalidades-a-pratica-de-assediomoral-nas-dependencias-da-administracao-publica-municipal-direta-e-indireta-porservidores-publicos-municipais-2003-07-3I-versao-consolidada Acesso em: 26 out. 2020.

"Vítima de assédio moral não tem a oportunidade de gozar seus direitos sociais no ambiente de trabalho" - Agência Brasil, Rio de Janeiro, io set. 2015. Disponível em: https://agenciabrasil.ebc.com.br/geral/noticia/2015-o9/vitima-de-assedio-moral-nao-gozadireitos-sociais-no-trabalho-diz-procurador Acesso em 3 out. 2020. 